\title{
REVIEW
}

Gender and Equality in Muslim Family Law: Justice and Ethics in the Islamic Legal Tradition, ed. Ziba Mir-Hosseini, Kari Vogt, Lena Larsen, and Christian Moe, 2013. London and New York: I.B. Tauris, vii + 279 pp, £17.99. ISBN: 978-1-7845-3740-1.

\section{Tim ORR}

Indiana University-Purdue University Columbus, Columbus, Indiana, USA tmorr@iupui.edu

The conflict addressed by the book Gender and Equity in Muslim Family Law centres on how religious authority in Islam is understood. The authors charge that the classical position within Islam, with its adherence to the fiqh tradition as immutable, employs a patriarchal understanding of gender. This understanding of inequality is taken for granted by the authors of early Islamic jurisprudence and reflects the values of their day. The authors challenge the classical Islamic jurisprudence that said women were created for men, are defective in reason and faith, and are destined to live in a world where men are superior to women.

The book analyses the political and hermeneutical obstacles to gender equality in Islam. It begins with an introduction by the four editors, Ziba Mir-Hosseini, Kari Vogt, Lena Larsen, and Christian Moe, who define the book's purpose. They set out to provide a forum for diverse scholarly voices who address the problems for women in Islam that stem from the traditional understanding of the Arabic terms qiwāma and wilàya. These terms connote a form of guardianship that places men as heads over women as men are to serve as guardians and breadwinners in their respective homes. The guardian role, according to the traditional understanding, puts much power in men's hands to supervise the decisions of women, especially when it comes to marriage. The authors of this book assume that classical jurists believed that women were incapable of making those decisions independently. In response, the authors of each chapter make their argument for various strategies of reform.

In the introductory essay, Ziba Mir-Hosseini lays the foundation for the book by explaining how gender justice is played out in both politics and theology. She also lays the groundwork for the significant problems dealt with in the book, namely men's authority over women, and the need to address what she sees as the deficiencies of family law.

Chapters 2 to 5 explain the political perspectives influenced by Muslim family law that need reform. Mulki Al-Sharmani examines how the man's role of guardianship over his wife shapes an understanding of women's rights by investigating the usage of the word qiwäma in Egyptian family law, and how the command of wifely obedience is reflected in legal texts, courtroom practices, and marriage. She also shows how Egyptian women's NGOs have impacted personal status law reform. Then Aïcha El Hajjami addresses reform in the Moroccan family code regarding the legislature's attempts to make significant changes in controversial areas of family law. In the final chapter in this section, Zainah Anwar 
introduces Musawah, an organization that attempts to create a global movement to achieve gender equality within Muslim families.

Chapters 6-10 address the hermeneutical changes needed to bring about gender justice. First, Muhammad Khalid Masud shows that, while the majority of jurists are religious conservatives, there have been diverse opinions regarding the meaning of wiläya. Next, Nasr Abu-Zayd undertakes to demonstrate that classical fiqh is inconsistent with modern human rights, arguing for the necessity of contextualizing the Qur'an to foster a rereading. This section also critiques the assumption of male authority in classical fiqh. Faqihuddin Abdul Kodir offers a way to rethink this assumption, charging that Islam did not seek to construct a top-down approach to gender relations. The section concludes with Mohsen Kadivar's proposed explanation of how justice is to be understood, in which he juxtaposes a desertsbased justice that espouses proportional equality, with an egalitarian view of justice. He shows how Muslims can reread the Qur'an through an egalitarian lens. The book concludes with Anver M. Emon's thoughtful consideration of the paradox of equality.

One strength of this book is its contribution to the debate regarding criticism of classical fiqh and the discussion between two positions, namely the classical fiqh vs. a contemporary understanding of fiqh. An assumption of classical fiqh is the role that certainty plays in the decisions of the classical jurists. These jurists left God's ruling to authoritative experts whose decisions were immutable and looked at their choices as synonymous with God's opinion. On the other side we find the modern jurists, who do not seek absolute certainty, as all jurists are fallible and do not make correct decisions every time. Modern jurists are also open to a broader range of evidence, thereby opening themselves to human reason much more.

One example of the strength of this modern view is presented is in the chapter titled 'Gender Equality and the Doctrine of Wiläya', where Muhammad Khalid Masud details the evolution that has taken place through the centuries regarding the Islamic understanding of wilaya (marriage guardianship) due to continual changing social contexts. He shows that even classical jurists were divided on this issue, as diverse positions on guardianship were held by each of the four schools of Islamic law in the Sunni tradition. The term '[g]uardianship (wilāya/walāya) means the legal authority to manage the affairs of another person who lacks the required capacity. The presence of a marriage guardian (wali al-nikāh) is a formal requirement for the valid contract of a marriage' (128).

The reason for this evolution is rooted in an inherent flexibility in how in how sharica law is applied. For instance, in Sunni jurisprudence, there are four sources of sharica, which are the Qur’an, sunna, consensus, and analogy (qiyās). It is the fourth source, analogy, that has been the source of evolving understandings of many concepts in Islam. Analogy involves comparing and contrasting the teachings of the Qur'an and sunna and looking to the previous rulings as they apply to the new circumstances that have brought on the need for a new ruling. It is the process of analogy that creates an ongoing change in how sharica is applied. Masud informs the reader that the differences in interpretation are rooted in the application of analogy to a given situation each time a new situation arises.

Masud also points out that there is a threefold process that uncovers the understanding and application of the text. The process begins by interpreting the text, using either classical methods that focus on the meaning of the words of the text or more contemporary approaches that utilize objective, subjective, or theological methods of interpreting. The 
second step in the process is construction, which involves applying the text to one's situation. The third step is a reconstruction of the text and the process relevant to the topic under discussion, and it is this step that enables understanding and application of the text to evolve over time. Masud utilizes this method of reconstruction to show how the understanding and application of the word wilaya evolved.

Another strength of the book is Anver M. Emon's chapter on equality titled The Paradox of Equality and the Politics of Difference: Gender Equality, Islamic Law, and the Modern State. Emon approaches the subject of equality by examining the nuances of how one practically applies it in real life. There are at least two understandings of equality one can adopt. One is the 'rights-based method', rooted in the political ideology of liberal democracy, which views equal rights in every sphere of existence. The other entails a more differentiated understanding of equality, where difference can be justified by a presumption of naturalness, acknowledging that men and women are different in some areas.

To ensure justice takes place, Emon argues that men and women may need to be treated differently in order to ensure equality, viewing this differential as rooted in the principle of naturalness, a term that describes gender in terms of differences that are inherently natural. For instance, the principle might indicate that a woman may be better suited to raise an infant child. If a divorce occurs, she may get custody of the infant child because she is seen as better qualified to raise an infant given her gender. Thus, she would have rights her husband does not have. Conversely, a court might regard the husband as better suited, based on his gender, to raise his teenage son. This position is what Emon calls the 'paradox of equality'.

One can quickly see how the principle of naturalness can easily become a rationalization for discrimination if applied as strict Aristotelian essentialism. Thus, it is easy to see how gender differences can become a rationalization for gender oppression. Knowing this, Emon calls for a thorough scrutinizing of this differentiation. But finally, he sees this 'paradox of equality' as allowing Muslims to examine their sacred texts as a framework for formulating the sort of proportional gender equality that can be seen as implicit in these texts. While many legal rulings regarding gender might be considered discriminatory in our contemporary culture, Emon's reasoning suggests that rulings that differentiate between men and women may be, in fact, just.

The book accomplishes its goal by exploring the political and hermeneutical challenges that hinder gender equality from being fully realized by scrutinizing Islamic texts and jurists' opinions. The lay Muslim and the scholar can both benefit from this book. Many lay Muslims, particularly in the West, are encountering challenges to their faith as they seek to live it out in a contemporary setting, since the authors of this book provide them with new perspectives on how to answer present-day problems located in Muslim family law. Scholars can also benefit from this book, as many problems highlighted in scholarly publications are addressed here in fresh new ways. 